\title{
Factors Affecting Students Continue Intention to Use MOOCs, Benefits and Drawbacks. A Research Paper from the UAE Context
}

\author{
Palanati Durga Prasad, K.V.N.Sunitha, B.Padmaja Rani
}

\begin{abstract}
In the twenty-first century, universities have misplaced their monopoly of the production and transmission of knowledge. They face the assignment of adapting to the needs of society, which can be summarized in three key aspects: economy, science and school development. The use of information communication technology has become the main concern for almost all educational institutions due to its cost efficiency that makes it affordable for all students regardless their economic condition and time effectiveness regardless the physical location. These magnificent advantages motivated not only educational institutions but also the ministries of education in most of the countries to adopt this technology as a key driver for socioeconomic development and illiteracy eradication. The UAE has its own agenda in adopting MOOCs in education system and at the heart of them is improve the quality of education. Despite, these advantages, many challenges still surround this vital technology. Thus, this research is a review paper on the introduction to MOOCs, its advantages and challenges and the trend for future research from the $U A E$ perspective.
\end{abstract} $\boldsymbol{U A E}$

Keywords-Factors, Students, MOOCs, Continue, intention,

\section{INTRODUCTION}

Having first manifested around 2007, MOOCs is becoming more acquainted as a sensation within the realm of education. MOOCs might be depicted as online productions transcendently university partnered that ordinarily draw in a multitude of university affiliations, and which are open in that they allow open content and wider access for admissions to instructional materials (G Kennedy, 2014). In this manner, having open access and right of admission to and unlimited number of individuals, appears to be two of the focal highlights of MOOC. (Rodriguez et al., 2013) depicted the openness aspect as relating to open software, the absence of rigor in way of enrolment, open statistics sources, open state of the guides themselves, having open evaluation criteria and furthermore inexperienced individuals receptive to new ideas. The legitimate reason for MOOCs used to be, to give free university level tutoring for the numerous students as deemed practical (Yuan \& Powell, 2013). At the beginning of the education revolution, the scope of Massive Open

Revised Manuscript Received on April 12, 2019.

Salem Abdullah Aldahmani,Institute of Technology Management and Entrepreneurship, UniversitiTeknikal Malaysia Melaka, C-ACT. (E-mail: aldahmani.83@hotmail.com)

Samer Ali Al-shami, Institute of Technology Management and Entrepreneurship, UniversitiTeknikal Malaysia Melaka, C-ACT.

MuhamadAfzamimanAripin, Institute of Technology Management and Entrepreneurship, UniversitiTeknikal Malaysia Melaka, C-ACT.
Online Courses (MOOCs) has improved in current years. Exhibiting incredible contrasts from past procedures to online training, MOOCs is at the forefront in the development of open instructive assets for students around the globe. MOOCs are viewed as current advancement in on-line learning having virtual technology enhanced real time situations.

\section{EDUCATION DEVELOPMENT IN THE UAE}

Tertiary training foundations in the UAE are getting ready understudies for a quickly changing data and technology driven world. The development of technological education was taken by the government as a key to meet the needs of graduates who are prepared for the work environment and who have an abnormal state of information and trust in the utilization of technology to help them in their long lasting learning. The UAE is a little nation of around four million tenants, arranged at the toe of the Arabian Peninsula and is limited by the Kingdom of Saudi Arabia and the Sultanate of Oman. Driven by oil disclosures, the UAE's lively economy has encountered phenomenal monetary development over the most recent 10 years. Depicted as a standout amongst the most-wired nations on earth the UAE has been brought into the globalized world in the course of the most recent a long time since being a devastated area of little desert territories to turning into an advanced free nation (Sbia, Shahbaz, \& Ozturk, 2017). The United Arab Emirates (UAE) in 1995 was among the soonest nations to allow its natives access to the Internet (Mirza \& Al-Abdulkareem, 2011). Universities and Higher Colleges of Technology in the UAE are progressively utilizing web based learning or elearning as it is more normally called, as a major aspect of the educational programs. E-learning is at present trendy term used to portray the various utilization of data and interchanges advancements to help and improve picking up, educating and appraisal from asset based learning (in which understudies do eye to eye assignments supplemented by a scope of online assets) to completely online courses (Marks \& Al-Ali, 2016). Learning based on online is regularly utilized conversely with the term e-learning. Few examinations have been completed in the UAE to research the utilization of e-learning in tertiary training. The greater

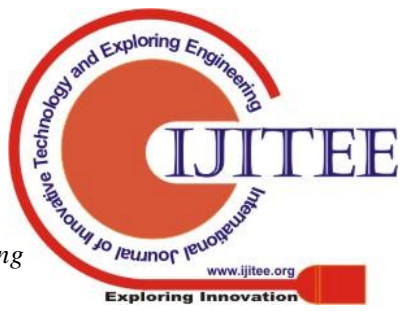


part of studies have concentrated on the view of the teachers about acknowledgment eLearning (Parkman, Litz, \& Gromik, 2018), alongside understudies view of embracing elearning in the UAE s (Lee, Toufaily, \& Zalan, 2016). Other neighbourhood thinks about spotlight on dialect skill and dialect use to get to the Web (Gokah, Gupta, Ndiweni, \& Watt, 2015).

Policy talks in Dubai distinguish the country as expecting to establish a technology driven economy. This requires suitable methods of instruction and preparation which a few specialists see as the quickest and best course to accomplish change (Gokah et al., 2015) In spite of the quick ascent of hyper-media, e-learning is as yet not used in certain schools in Dubai. This might be because of technology seating awkwardly with exacting cultural and social policy or instructors being aware of state backlashes in the event that things turn out badly in its use (Pratley et al., 2018) As an activity to reinforce education essentially based on technology, the UAE expected to set up a provincial instructive center point to meet the administration's 2021 Vision "an information based society so as to contend proficiently on the global stage" (Annabi \& Muller, 2016) The United Arab Emirates Service of Higher Education and Scientific Research underpins Vision 2021's thoughts of advancement with a subculture fostering innovativeness with the guide of concentrating on neighbourhood needs and offsetting instructing with work needs (Annabi \& Muller, 2016). For governments to guarantee financial accomplishment in the information, economy reliance on "logical and mechanical learning, and on determined development" is needed (Naidoo, Shankar, \& Veer, 2011) . (Findlow, Goulermas, Nester, Howard, \& Kenney, 2008) opined anxiety as what remains in "financial bureaucratic models of HE" and education advancement, it was further stated that development is considered as halfway responsible, for accentuation in "understudy capacities improvement, utilization of realities and verbal trade advances, advancement special procedures of evaluation and upgrading proficiency." Understudies are regarded as "faithful purchasers" (Higgins \& Thompson, 2002)(H Fry, S Ketteridge, 2009). This exploration contends that requests from learners and their expectations must be worked in inside IBC's teaching and acing procedures. Are MOOCs the appropriate response? Skills in Education Technology (ET) can enhance rapid growth (Biggs, 2003) ET offers "consistency with the transportation of instructional exercises, bringing down direction time and improving intellectual review and authority of learning"(Kala, Isaramalai, \& Pohthong, 2010)Active setting of HE needs creativity incorporating advanced skill levels. Where the computerized capacities of the amateurs are perceived to be progressive, the educational modules must be change to coordinate mechanical skill to facilitate "understudies participating in numerous types of learning" (Beetham, McGill, \& Littlejohn, 2009) Besides, with undergrads in the UAE communicating a loving of advanced frameworks (Wilkins \& Huisman, 2015), MOOCs can supply such a course, implementing the global plan of UAE and HE organizations.

\section{ORIGINS AND SCALE OF MOOCs}

In 2008, the term 'MOOCs' was created by David Cormier so as to depict an open online course entitled 'Connectives' and Connective Knowledge' given by Siemens and Downes at the University of Manitoba in Canada (C Baker,Layne, 2015; Sonwalkar1, 2015)This open course intrigued more than 2,300 understudies who joined to no end out of pocket (Sonwalkar,Maheshkar, 2015).In 2011, the second MOOC 'Prologue to Artificial Intelligence', to which in excess of 160,000 understudies picked (Brahimi \& Sarirete, 2015) was managed by Professor Sebastian Thrun, an instructor at the Stanford University and Peter Norvig, the authority of research at Google (Atiaja \& Guerrero-proenza, 2016)and the season of 2012 was called for MOOC (L Pappano, 2012).As the fame of MOOCs, Daphne Koller and Andrew $\mathrm{Ng}$ set up 'Coursera' as an organization with going for giving instruction high caliber to pull in understudies the world over (Brahimi \& Sarirete, 2015).Harvard University and MIT built up a non-benefit MOOC stage called edX(Yousef, Chatti, Schroeder, Wosnitza, \& Jakobs, 2014).Moreover, 'Udacity' was framed by David Stavens with Sebastian Thrun and Michael Sokolsky(L Pappano, 2012) and Future Learn was eaten by Open University to offer free courses dependent on online which was broadly utilized by various top colleges in the UK (Liyanagunawardena, Adams, \& Williams, 2013).The utilization of Open Education and MOOCs has been consistently developing since 2008 as appeared in Figure.1 embraced from (Powell, 2018).It was expressed that there were very nearly 6,850 courses given by in excess of 700 universities in 2017 (Shah, 2016a).

The development of MOOCs witnessed a rapidly growing between 2012 and 2017 (Shah, 2016a). Increased number of students counted in at least one course jumped to 58 millionin 2016 as reported by (Shah, 2016a). Nowadays, FutureLearn, Udacity, XuetangX, Edx, and Coursera, and whose total number of users of these platforms are 3 , 4,5,6,10 1nd 23 million, correspondingly, have been enlisted as the most astounding MOOCs suppliers as far as the quantity of enrolled clients (Shah, 2016a).

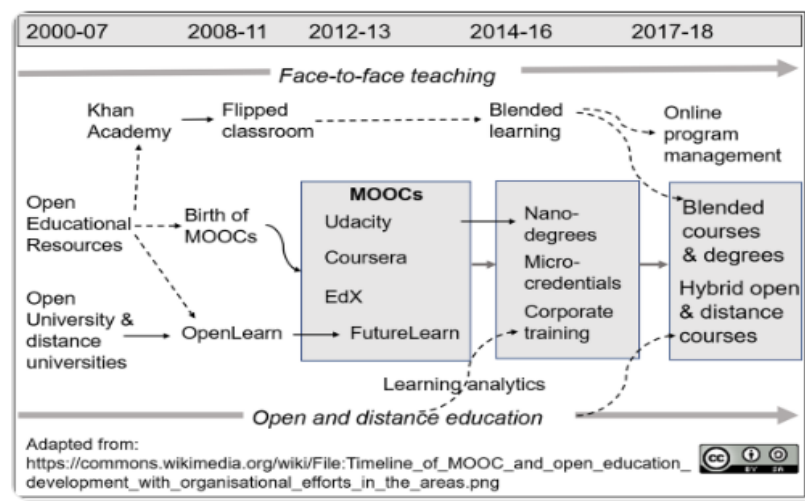

Figure 1 Timeline of MOOCs and Open Education (Powell, 2018). 
As to number of offered courses, the best MOOCs suppliers are Coursera, EdX, FutureLearn, Miríada X, and XuetangX with 1700+, 1300, 480, 350, and 300+ offered courses, freely (Shah, 2016a). Most of MOOC courses are offered in 3 key tongues: English, Spanish, and French with 6,287, 634, and 323 courses, autonomously (Class Central, 2017). Particular courses are by and by being offered in upwards of 15 remarkable dialects as illustrated in Figure 2 (Class Central, 2017).

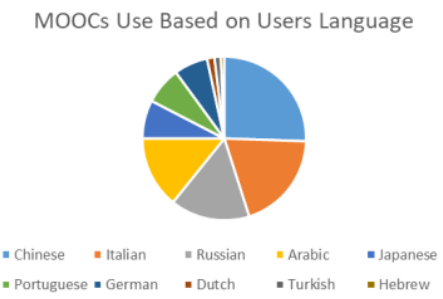

Figure.2: The Use of MOOCs Based on Language (Class Central, 2017).

\section{MOOCs' TYPES: cMOOCs AND xMOOCs}

Nowadays, 'cMOOCs' and 'xMOOCs' have been widely recognized as the two main divergent types of MOOC based on their pedagogical design (Yousef et al., 2014). On one hand, the cMOOCs (accessibility MOOCs) pursue the idea of learning based on social networ, where the information and substance are produced by the members as they advance through the course (Wang, Anderson, Chen, \& Barbera, 2017). In cMOOCs, the students themselves have can control the course by defining the objectives of the course, making substance and exercises, and appropriating the information to different members (Skrypnyk, Joksimović, Kovanović, Gasšević, \& Dawson, 2015). Students in cMOOCs team up and share information utilizing Web 2.0 advances, for example, sites, wikis, Google gatherings, Facebook, and other person to person communication devices.IncMOOCs there is no formal appraisal, be that as it may, a casual criticism can be shed by the members or attempt self-evaluation (Pilli \& Admiraal, 2016).Instances, of cMOOCs join CCK117 (Connectivism and Connective Knowledge), PLENK6 (Personal Learning Environments, Networked Knowledge), ChangeMOOC8, etMOOC9, etc(Yeager, Hurley-Dasgupta, \& Bliss, 2013). Figure3 showcases the fundamental ideas of cMOOCs(Yousef et al., 2014).

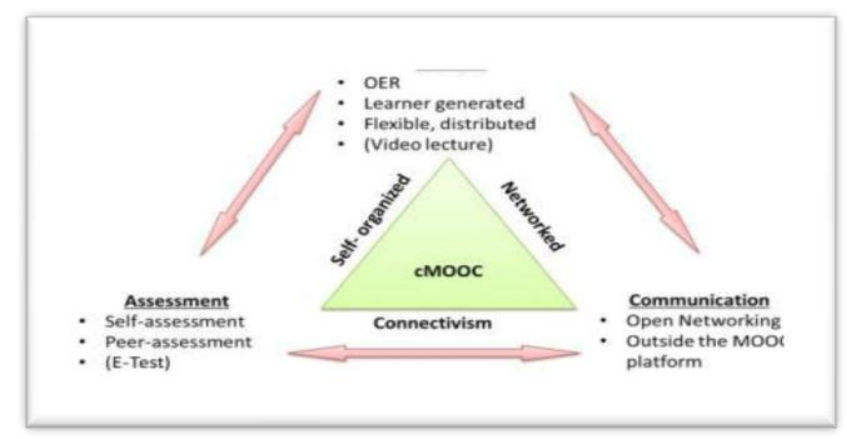

Figure 3 Main conceptions of cMOOCs(Yousef et al., 2014).
The central MOOCs today, provided by suppliers such as Udacity, Coursera, edX, etc., are called xMOOCs (extension MOOCs) and are based on cognitivist learning/ behavioral (Lin, 2017; Luo, Zhou, Li, \& Xiao, 2018). xMOOCs are formal courses sorted out additionally to standard insightful courses, introducing video addresses, content based readings, tests, and assignments as the rule learning works out. Educators in xMOOCs expect assume a noteworthy job building up the substance, choosing the courses' objectives, and looking over the understudies(Janssen, Nyström Claesson, \& Lindqvist, 2016). Educators and understudies in xMOOCs ordinarily emerge in an incorporated discussion gathering (inside the course stage). Understudies are surveyed by the educators of the courses through different methodologies, for example, tests, various decision tests, assignments, and companion valuation by means of rubrics planned by the teachers (Cinquin, Guitton, \& Sauzeon, 2019).. As reported by (Yousef et al., 2014), the principle ideas of xMOOCs incorporate three fundamental parts to be specific substance, appraisal and correspondence in which every segment has a few methodologies that are utilized adequately and together to perform learning result which are shown in Figure4. There are new kinds of MOOCs, for example, mixed MOOCs (bMOOCs) which are blending MOOCs face-to-face and online communication and smOOCs which refer to small scale open online programmes with a very modest number of clients (Yousef et al., 2014).

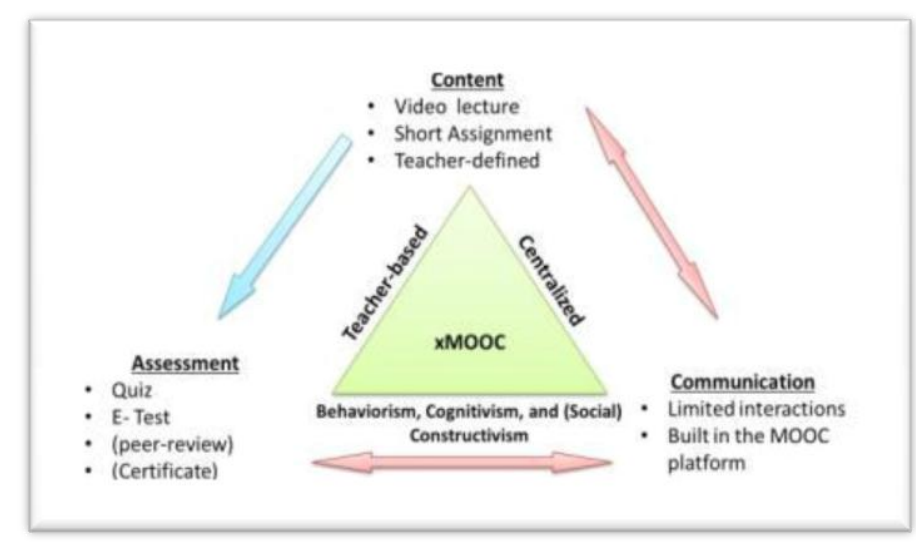

Figure 4 Main concepts of xMOOCs(Yousef et al., 2014).

\section{MOOCs' PEDAGOGY}

For the most part, MOOCs' pedagogics depend amazingly on the accompanying necessities(Mohamed \& Hammond, 2018; Pundak, Sabag, \& Trotskovsky, 2014). 1. A schedule: the subjects in the course with the learning result. 2. Readings and video addresses: in xMOOCs, these assets are much of the time filed while in cMOOCs, the administrators in addition week after week pass on an introduction or welcome a visitor instructor. 3. Discussions: where the greater part of the learning interfaces happen. In xMOOCs, focal thoughts discussions are typically abused, while on account of cMOOCs, the spread open spaces (generally 
writes, wikis, Facebook pages, and so on.) are utilized. 4. Assignments, tests, and ventures: are utilized for students' evaluation; may prompt confirmation. The video of the recorded addresses regularly last 5-15 minutes. In any case, there are accounts that keep going up to an hour or more. In the midst of an address, questions are given in order to assess the understudies' appreciation of the discussed focuses in the location. In like manner, understudies obtain seven days after week task as a noteworthy part of evaluation. Customarily, an enormous number of understudies take part in a course, which, when in doubt, is managed by a focal speaker and other 2-3 teaching helpers. At present, by far most of MOOCs' courses seek after an intensive timetable, which infers that the understudies must present their without fail assignments on schedule in order to complete the courses viably. Opposite, there are selfguided courses which are versatile and don't contain due dates. Be that as it may, such flexibility may incite works' deferment (Pundak et al., 2014). The assessment of endless positions is one of the issues of MOOCs, and can be understood with the associated approaches (Pundak et al., 2014): 1. Programmed testing utilizing closed questions; 2. Peer evaluation; and 3. Test through artificial intelligence. In the wake of completing the course, an understudy may can pick up an endorsement (Joo, So, \& Kim, 2018; Pundak et al., 2014).

\section{MOOCs' BENEFITS AND DRAWBACKS}

MOOCs special qualities are recognized from customary web based courses. Below are key highlights that are qualities distinguishinglearning in MOOCs (Badi \& Ali, 2016) 1. Vastness: the stages are versatile where the courses can bolster huge quantities of students. 2. Openness, the courses are available to anybody to take an interest whenever and from anyplace for nothing without duty or earlier prerequisites. 3. Assorted Diversity (heterogeneity): the members are from different societies, foundations, and have different inspirations. Similarly, as with any learning system, MOOCs have points of interest and impediments. The advantages of MOOCs incorporate the accompanying: 1. Improve knowledge and skills which in case develop a lifelong learning 2. Offer an opportunity to interchange thoughts, opinions, and knowledge with other partners who share the same awareness (Donitsa-Schmidt \& Topaz, 2018), 3. provide a great chance to be part of courses with high quality that are provided by well-known professors in admired educational institutions across the world (Kaplan \& Haenlein, 2016),4. Eliminate time and place restraints, obstacles of high charge, as well as preconditions and obligation related to the traditional colleges (Evans, Baker, \& Dee, 2016), 6. Improve the cross-cultural relations as a result of communication among participants from dissimilar cultures and nations (Luetkehans, 2016).

Notwithstanding the numerous educational advantages that offer by MOOCs, there are number of obstacles: - 1 . Lack of quality interaction between the lecturers and students which affect learning quality ( $\mathrm{Li}$, Tang, Cao, \& Hu, $2018)$; 2. the absence of interaction with teachers, real-time question answering and feedbacks, due to disproportionate student-teacher ratio in a single course (Atiaja \& Guerrero- proenza, 2016); 3. The dropout rate from MOOCs is very high where the achievement proportion ranking between 515\% (Xing, Chen, Stein, \& Marcinkowski, 2016); 5. Limited effectiveness to non-English presenters as most of accessible MOOCs are open in English language. Furthermore, not all resources are socially suitable for all listeners (Amado-salvatierra, 2017). 6. Authentication: struggle to confirm that the individual who takes test online is the same individual who registered in the course (Sonwalkar1,2015). 7. Anxieties about the credit of certificates gained from the platforms by companies and colleges due to the absence of standards for quality through MOOC platforms (Garrido, Koepke, Andersen, \& Garrido, 2016). 8. Low incentive to contribute in MOOCs and finish the courses owed to the fact that education in MOOCs is mostly self-orientation which involves obligation and selfmotivation rather than career motivation (Barak, Watted, \& Haick, 2016).

\section{MOOCS ISSUES IN UAE CONTEXT AND FUTURE RESEARCH\& RESULTS}

Although much controversy surrounds around the idea of MOOCs, they are becoming dominant in the online educational market by attracting thousands of students. MOOCs have been cited as the most beneficial to increasing accessibility, potential for student engagement, and expanding lifelong learning opportunities (Joo et al., 2018; Pundak et al., 2014). As an activity to reinforce education essentially based on technology, the UAE expected to set up a provincial instructive center point to meet the administration's 2021 Vision "an information based society so as to contend proficiently on the global stage"(Annabi \& Muller, 2016). The United Arab Emirates Service of Education underpins Vision 2021's thoughts of advancement with a subculture fostering innovativeness with the guide of concentrating on neighborhood needs and offsetting instructing with work needs(Annabi \& Muller, 2016). For governments to guarantee financial accomplishment in the information, economy reliance on "logical and mechanical learning, and on determined development" is needed (Naidoo et al., 2011) MOOCs are exploited to enhance teaching and learning. On the one hand, MOOCs offer teachers the opportunity to reach a large number of students worldwide (Alario-Hoyos, Prez-Sanagust, Cormier, \& Delgado-Kloos, 2014). On the other hand, MOOCs enable students to access free and open education provided by the most reputable universities, which attract substantially larger audiences than traditional online education. Furthermore, MOOCs are communities of people that share common interests (Alario-Hoyos et al., 2014; Czerniewicz, Glover, Deacon, \& Walji, 2016). A dozen MOOCs in UAE have been developed and published on MOOCs platforms such as Coursera and edX. In UAE many schools have promoted and launched MOOCs programs to enhance quality of their educational standards and services.

Despite public enthusiasm for MOOCs, it has been observed that MOOCs suffer from enormous dropout rates. On average, less than $10 \%$ of students attending MOOCs

Published By:

Blue Eyes Intelligence Engineering \& Sciences Publication 
complete their course (Steffens et al., 2015). Considering the issue of MOOCs dropout and non-completion rates, a subject of great concern has been centered on issues of quality in learning and teaching (Al-shami, Sedik, Rashid, \& Hussin, 2018c; Diver \& Martinez, 2015) However, completion rate may not be the best measure for evaluating learning in MOOCs (Jordan, 2015), because students enrol in MOOCs for a variety of reasons (Al-shami, Sedik, Rashid, \& Hussin, 2018a).

Considering the rapid development and adoption of MOOCs for distance learning, an investigation of factors that influence students' continued usage of MOOCs may reveal insights into its viability (Bhattacherjee \& Premkumar, 2004) and sustainability (Al-shami, Sedik, Rashid, \& Hussin, 2018b). However, a limited amount of research has examined the factors that influence MOOCs continuance intention. In addition, MOOCs learning can be considered the behavior of users to obtain, use and spread MOOCs resources. This behavior includes two stages: the first stage is users' perception of MOOCs by attitude, adoption and habits; the second stage is the extent to which MOOCs meet the needs of users, which emphasizes the utility of MOOCs. Nevertheless, few studies have investigated how students' intention to participate in MOOCs through combing both views.

The technological features and competencies plays a major role in persisting use technology. It is because the technology users can be pushed by motivated such as easy to use and perceive usefulness, but continue using technology requires quality of the used technology. However, few studies combine both motivational and technological factors that influence continuous intention to use MOOCs. In addition, the context factors such as the language and the cost of the course influence the use of MOOCs. Yet, few studies investigated how MOOCs work in particular environment such as Arab region where the MOOCs are provided Arab language and free of charge.In addition, this research is one of few researches that investigate the use of MOOCs. Therefore, we argue that the continue intention to use technology in general and MOOCs particularly depends not only on specific motivational factors that influence users' behaviour, but also technological features as well as context factors as shown in Figure 5.

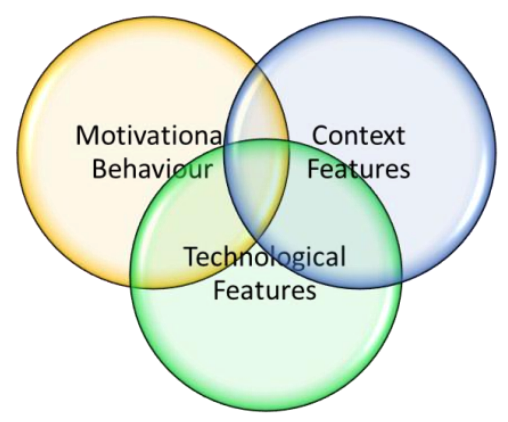

Figure 5: Factors affecting Continuous Intention to Use MOOCs

Therefore, examines how the continues intention to use MOOCs can be influenced by motivational factors, technological features and context factors is important which is the central aim of this research

\section{REFERENCES}

1. Al-shami, S. A., Sedik, S., Rashid, N., \& Hussin, H. (2018a). An empirical Analysis of MOOC Adoption from the Perspective of Institutional Theory. Jour of Adv Research in Dynamical \& Control Systems, 10(6), 332-343.

2. Al-shami, S. A., Sedik, S., Rashid, N., \& Hussin, H. (2018b). Empirical, Analysis, MOOCs, Adoption, Institutional, Theory. Journal of Advanced Research in Dynamical and Control System, (6), 332-343.

3. Al-shami, S. A., Sedik, S., Rashid, N., \& Hussin, H. (2018c). The Barriers That Influence the Use of Moocs. Case Study from University Teknikal Malaysia Melaka (Utem). Jour of Adv Research in Dynamical \& Control Systems, 10(6), 310321.

4. Alario-Hoyos, C., P??rez-Sanagust??n, M., Cormier, D., \& Delgado-Kloos, C. (2014). Proposal for a conceptual framework for educators to describe and design MOOCs. Journal of Universal Computer Science.

5. Amado-salvatierra, H. R. (2017). Programa de Doctorado en Ingeniería de la Información y del Conocimiento Departamento de Ciencias de la Computación ENSEÑANZA BASADA EN E-LEARNING HÉCTOR RODERICO AMADO https://doi.org/10.13140/RG.2.2.26826.88006

6. Annabi, C. A., \& Muller, M. (2016). Learning From the Adoption of MOOCs in Two International Branch Campuses in the UAE. Journal of Studies in International Education, 20(3), 260-281. https://doi.org/10.1177/1028315315622023

7. Atiaja, L., \& Guerrero-proenza, R. S. (2016). The MOOCs: origin, characterization, principal problems and challenges in Higher Education. Journal of E-Learning and Knowledge Society, 12(February 2016), 65-76.

8. Badi, D. S., \& Ali, D. M. E. A. (2016). Massive Open Online Courses (MOOC) Their Impact on the Full Quality in Higher Education Institutions "Rwaq: Saudi educational platform for MOOC". Journal of Library and Information Sciences, 4(1) https://doi.org/10.15640/jlis.v4n1a6

9. Barak, M., Watted, A., \& Haick, H. (2016). Motivation to learn in massive open online courses: Examining aspects of language and social engagement. Computers and Education, 94, 49-60. https://doi.org/10.1016/j.compedu.2015.11.010

10. Beetham, H., McGill, L., \& Littlejohn, A. (2009). Thriving in the 21st century: the report of the LLiDA project (Learning Literacies for the Digital Age): Conclusions and recommendations. A JISC Funded Study, (June), 1-20.

11. Bhattacherjee, \& Premkumar. (2004). Understanding Changes in Belief and Attitude toward Information Technology Usage: A Theoretical Model and Longitudinal Test. MIS Quarterly. https://doi.org/10.2307/25148634

12. Biggs, J. B. (2003). Aligning teaching and assessing to course objectives. Teaching and Learning in Higher Education: New Trends and Innovations https://doi.org/10.1080/02602938.2012.670197

13. Brahimi, T., \& Sarirete, A. (2015). Learning outside the classroom through MOOCs. Computers in Human Behavior, 51, 604-609. https://doi.org/10.1016/j.chb.2015.03.013

14. C Baker,Layne, M. (2015). Volume 4 , Number 2 - Fall 2015 (C) 2015 Policy Studies Organization Table of Contents. Internet Learning Journal, 4(2), 1-119.

15. Cinquin, P.-A., Guitton, P., \& Sauzeon, H. (2019). Online elearning and cognitive disabilities: A systematic review To cite this version: HAL Id : hal-01954983 Online e-learning and Cognitive disabilities : a. Computers and Education, 1320, $152-167$

16. Czerniewicz, L., Glover, M., Deacon, A., \& Walji, S. (2016). MOOCs , openness 
and changing educator practices: an Activity Theory case study. In Proceedings of the 10th International Conference on Networked Learning 2016.

17. Diver, P., \& Martinez, I. (2015). MOOCs as a massive research laboratory: opportunities and challenges. Distance Education, 36(1) https://doi.org/10.1080/01587919.2015.1019968

18. Donitsa-Schmidt, S., \& Topaz, B. (2018). Massive open online courses as a knowledge base for teachers. Journal of Education for Teaching, 44(5), 608-620 https://doi.org/10.1080/02607476.2018.1516350

19. Evans, B. J., Baker, R. B., \& Dee, T. S. (2016). Persistence Patterns in Massive Open Online Courses (MOOCs). The Journal of Higher Education, 87(2), 206-242. https://doi.org/10.1353/jhe.2016.0006

20. Findlow, A., Goulermas, J. Y., Nester, C., Howard, D., \& Kenney, L. P. J. (2008). Predicting lower limb joint kinematics using wearable motion sensors. Gait and Posture. https://doi.org/10.1016/j.gaitpost.2007.11.001

21. G Kennedy. (2014). An introduction to corpus linguistics.

22. Garrido, M., Koepke, L., Andersen, S., \& Garrido, M. (2016). The Advancing MOOCs for Development Initiative An examination of MOOC usage for professional. Seattle: Technology \& Social Change Group, University of Washington Information School.

23. Gokah, T. K., Gupta, N., Ndiweni, E., \& Watt, H. (2015). ELearning in Higher Education - Opportunities \& Challenges for Dubai . International Journal on ELearning

24. H Fry, S Ketteridge, S. M. (2009). A handbook for teaching and learning: Enhancing academic practice.

25. Higgins, J. P. T., \& Thompson, S. G. (2002). Quantifying heterogeneity in a meta-analysis. Statistics in Medicine. https://doi.org/10.1002/sim.1186

26. Janssen, M., Nyström Claesson, A., \& Lindqvist, M. (2016). Design and Early Development of a MOOC on "Sustainability in Everyday Life": Role of the Teachers. In New Developments in Engineering Education for Sustainable Development (pp. 113-123.). https://doi.org/10.1007/978-3319-32933-8

27. Joo, Y. J., So, H. J., \& Kim, N. H. (2018). Examination of relationships among students' self-determination, technology acceptance, satisfaction, and continuance intention to use $\mathrm{K}$ MOOCs. Computers and Education, 122, 260-272. https://doi.org/10.1016/j.compedu.2018.01.003

28. Jordan, K. (2015). Massive open online course completion rates revisited: Assessment, length and attrition. International Review of Research in Open and Distance Learning.

29. Kala, S., Isaramalai, S. arun, \& Pohthong, A. (2010). Electronic learning and constructivism: A model for nursing education. Nurse Education Today.

30. Kaplan, A. M., \& Haenlein, M. (2016). Higher education and the digital revolution: About MOOCs, SPOCs, social media, and the Cookie Monster. Business Horizons, 44(5), 608-620. https://doi.org/10.1016/j.bushor.2016.03.008

31. L Pappano. (2012). The Year of the MOOC-The New York Times.

32. Lee, D., Toufaily, E., \& Zalan, T. (2016). Is the Avalanche of E-learning Coming to the UAE? In In: Benlamri R., Sparer M. (eds) Leadership, Innovation and Entrepreneurship as Driving Forces of the Global Economy. Springer Proceedings in Business and Economics. Springer, Cham.

33. Li, J., Tang, Y., Cao, M., \& Hu, X. (2018). The moderating discussion and satisfaction with MOOCs. Journal of Computers in Education, 5(3), 279-296. https://doi.org/10.1007/s40692-018-0112-2

34. Lin, J. (2017). Exploring the Experiences of Instructors Teaching Massive Open Online Courses in Tourism and Hospitality: A Mixed Methods Approach. Universitàdella https://doi.org/10.1016/j.nedt.2009.06.002 effects of discipline on the relationship between asynchronous

Svizzera italiana. $\quad$ Retrieved from http://doc.rero.ch/record/306564/files/2018COM001.pdf

35. Liyanagunawardena, T. R., Adams, A. A., \& Williams, S. A. (2013). MOOCs: A systematic study of the published literature 2008-2012. International Review of Research in Open and Distance Learning, 14(3), 202-227. https://doi.org/10.19173/irrodl.v14i3.1455

36. Luetkehans, L. M. (2016). Undergraduate Students' opinions with regard to ubiquitous MOOC for enhancing cross cultural competence. Educational Technology: Current Issues, 8(3), 210-217.

37. Luo, Y., Zhou, G., Li, J., \& Xiao, X. (2018). Study on MOOC scoring algorithm based on Chinese University MOOC learning behavior data. Heliyon, 4(11), e00960. https://doi.org/10.1016/j.heliyon.2018.e00960

38. Marks, A., \& Al-Ali, M. (2016). Analytics within UAE higher education context. In 2016 3rd MEC International Conference on Big Data and Smart City, ICBDSC 2016 (pp. 368-373). https://doi.org/10.1109/ICBDSC.2016.7460396

39. Mirza, A. A., \& Al-Abdulkareem, M. (2011). Models of elearning adopted in the Middle East. Applied Computing and Informatics, $\quad 9(2)$, https://doi.org/10.1016/j.aci.2011.05.001

40. Mohamed, M. H., \& Hammond, M. (2018). MOOCs: a differentiation by pedagogy, content and assessment. International Journal of Information and Learning Technology, 35(1), 2-11. https://doi.org/10.1108/IJILT-072017-0062

41. Naidoo, R., Shankar, A., \& Veer, E. (2011). The consumerist turn in higher education: Policy aspirations and outcomes. Journal of Marketing Management. https://doi.org/10.1080/0267257X.2011.609135

42. Parkman, S., Litz, D., \& Gromik, N. (2018). Examining preservice teachers' acceptance of technology-rich learning environments: A UAE case study. Education and Information Technologies, 23(3), 1253-1275. https://doi.org/10.1007/s10639-017-9665-3

43. Pilli, O., \& Admiraal, W. (2016). A Taxonomy of Massive Open Online Courses. Contemporary Educational Technology, 7(3), 223-240.

44. Powell, S. (2018). Revisiting our 'MOOCs and Open Education Timeline. Retrieved February 2, 2019, from https://stephenp.net/2015/06/13/revisiting-our-moocs-andopen-education-timeline/\#comments

45. Pratley, R. E., Eldor, R., Raji, A., Golm, G., Huyck, S. B., Qiu, Y., ... Lauring, B. (2018). Ertugliflozin plus sitagliptin versus either individual agent over 52 weeks in patients with type 2 diabetes mellitus inadequately controlled with metformin: The VERTIS FACTORIAL randomized trial. Diabetes, Obesity and Metabolism. https://doi.org/10.1111/dom.13194

46. Pundak, D., Sabag, N., \& Trotskovsky, E. (2014). Accreditation of Moocs. European Journal of Open, Distance and E-Learning, 17(2). https://doi.org/10.2478/eurodl-20140023

47. Rodriguez, J., Kazmierkowski, M. P., Espinoza, J. R., Zanchetta, P., Abu-Rub, H., Young, H. A., \& Rojas, C. A. (2013). State of the art of finite control set model predictive control in power electronics. IEEE Transactions on Industrial Informatics. https://doi.org/10.1109/TII.2012.2221469

48. Sbia, R., Shahbaz, M., \& Ozturk, I. (2017). Economic growth, financial development, urbanisation and electricity consumption nexus in UAE. Economic Research-Ekonomska Istrazivanja, 30(1), 527-549. https://doi.org/10.1080/1331677X.2017.1305792

49. Shah. (2016). By The Numbers: MOOCS in 2016. EMOOCs 2016, (December 25).

50. Skrypnyk, O., Joksimović, S., Kovanović, V., Gasšević, D., \& Dawson, S. (2015). Roles of course

Published By: 
facilitators, learners, and technology in the flow of information of a CMOOC. International Review of Research in Open and Distance Learning, 16(3), 188-217. https://doi.org/10.19173/irrodl.v16i3.2170

51. Sonwalkar1,*, M. (2015). Research Article Moocs : a Massive Platform for Collaborative Learning in, 2(June), 142-149.

52. Steffens, K., Bannan, B., Dalgarno, B., Bartolomé, A. R., Esteve-González, V., \& Cela-Ranilla, J. M. (2015). Recent Developments in Technology-Enhanced Learning: A Critical Assessment. RUSC. Universities and Knowledge Society Journal. https://doi.org/10.7238/rusc.v12i2.2453

53. Wang, Z., Anderson, T., Chen, L., \& Barbera, E. (2017). Interaction pattern analysis in cMOOCs based on the connectivist interaction and engagement framework. British Journal of Educational Technology, 48(2), 683-699. https://doi.org/10.1111/bjet.12433

54. Wilkins, S., \& Huisman, J. (2015). Factors affecting university image formation among prospective higher education students: the case of international branch campuses. Studies in Higher Education. https://doi.org/10.1080/03075079.2014.881347

55. Xing, W., Chen, X., Stein, J., \& Marcinkowski, M. (2016). Temporal predication of dropouts in MOOCs: Reaching the low hanging fruit through stacking generalization. Computers in Human Behavior. https://doi.org/10.1016/j.chb.2015.12.007

56. Yeager, C., Hurley-Dasgupta, B., \& Bliss, C. A. (2013). CMOOCS and global learning: An authentic alternative. Journal of Asynchronous Learning Network, 17(2), 133-147. https://doi.org/10.4018/jmbl.2012100103;

57. Yousef, A. M. F., Chatti, M. A., Schroeder, U., Wosnitza, M., \& Jakobs, H. (2014). MOOCs a review of the state-of-the-art. Csedu, 6(3), 9-21.

58. Yuan, L., \& Powell, S. (2013). MOOCs and Open Education: Implications for Higher Education. Retrieved March. 